\title{
Influence of Different Genres of Music on Static and Dynamic Balance Control of Young Adults
}

\author{
Farklı Müzik Türlerinin Genç Erişkinlerin Statik ve Dinamik Denge Kontrolüne Etkisi \\ Turhan KAHRAMAN ${ }^{1}$, Mahmut BEŞLi' ${ }^{2}$, Bayram ÜNVER ${ }^{3}$, Yeşim SALIK ŞENGÜL ${ }^{4}$
}

\begin{abstract}
Objectives: Since listening to music is very common while performing various activities of daily living among young adults, it is important to know its effects on balance control. This study aimed to examine the effects of different genres of music on static and dynamic balance control, especially during common activities of daily living such as sit-to-stand and walking, using both clinical and computerized balance assessment tools.

Materials and Methods: Thirty-six healthy young adults participated in this crossover study. Static balance was assessed using the modified Clinical Test Sensory Interaction on Balance in a computerized balance assessment device. Moreover, the dynamic balance during the common activities of daily living were assessed using the sitto-stand test and walk across test in the same device. The timed up and go test as a clinical measure was also used to assess dynamic mobility. All the tests were performed in different conditions, including without listening to music, listening to pop, rock, and classical music.

Results: There were 18 female and 18 male participants with a mean age of $23.0(S D=1.0)$ years. No statistically significant differences were found in the static and dynamic postural control variables $(p>0.05)$. Partial eta squared values indicated that the effect sizes were small.

Conclusion: This study showed that different genres of music including classical, rock, and pop do not influence the static and dynamic balance control in young adults. The influence of different genres of music with different frequency or groove properties on balance control and chronic effects of music should be investigated in future studies.
\end{abstract}

Keywords: Activities of daily living, music, postural balance

ÖZ

Amaç: Müzik dinlemek, genç erişkinler arasında çeşitli günlük yaşam aktiviteleri sırasında çok yaygın yapılan bir aktivite olduğu için müziğin denge kontrolüne etkisini bilmek önemlidir. Bu çalışmada, farklı müzik türlerinin statik denge ve özellikle oturup ayağa kalkma ve yürüme gibi günlük yaşam aktiviteleri sırasındaki dinamik denge kontrolü üzerindeki etkilerinin klinik ve bilgisayarlı denge değerlendirme araçlarını kullanarak araştırılması amaçlanmıştır.

Gereç ve Yöntemler: Otuz altı sağlıklı genç erişkin bu çapraz tasarımlı çalışmaya katıldı. Statik denge, bilgisayarlı denge değerlendirme cihazında modifiye Denge Duyu İnteraksiyonu Klinik Testi kullanarak değerlendirildi. Ayrıca, yaygın günlük yaşam aktiviteleri sırasındaki dinamik denge aynı cihazda, otur-kalk testi ve yürüme testiyle değerlendirildi. Klinik bir test olarak zamanlı kalk ve yürü testi de dinamik mobiliteyi değerlendirmek için kullanıldı. Tüm testler, müzik dinlemezken, pop, rock ve klasik müzik dinlerken olmak üzere farklı koşullar altında gerçekleştirildi.

Bulgular: Ortalama yaşları 23,0 $(S S=1,0)$ yıl olan 18 kadın ve 18 erkek katılımcı vardı. Statik ve dinamik postürel kontrol değişkenlerinde istatistiksel olarak anlamlı fark bulunmadı $(p>0,05)$. Parsiyel eta kare değerleri, etki büyüklüklerinin küçük olduğunu gösterdi.

Sonuç: $\mathrm{Bu}$ çalışma, klasik, rock ve pop gibi farklı müzik türlerinin genç erişkinlerde statik ve dinamik denge kontrolünü etkilemediğini gösterdi. Gelecekteki çalışmalarda farklı müzik türlerinin farklı frekans ve ritim özellikleri ile denge kontrolü ve bu müziklerin kronik etkileri araştırılmalıdır.

Anahtar kelimeler: Günlük yaşam aktiviteleri, müzik, postürel denge

Geliş Tarihi/Received:19.10.2018

Kabul Tarihi/Accepted: 26.02 .2019

${ }^{1}$ Department of Physiotherapy and Rehabilitation, Faculty of Health Sciences, Izmir Katip Celebi University, Izmir, Turkey. ORCID: 0000-0002-8776-0664

${ }^{2}$ School of Kemal Demir Physical Therapy and Rehabilitation, Abant Izzet Baysal University, Bolu, Turkey. ORCID: 0000-00015311-7390

${ }^{3}$ School of Physical Therapy and Rehabilitation, Dokuz Eylül University, Izmir, Turkey. ORCID: 0000-0002-9829-5884

${ }^{4}$ School of Physical Therapy and Rehabilitation, Dokuz Eylül University, Izmir, Turkey. ORCID: 0000-0003-2026-6765

Sorumlu yazar /correspondence: Turhan Kahraman, Asst. Prof. Dr., Department of Physiotherapy and Rehabilitation, Faculty of Health Sciences, Izmir Katip Celebi University, İzmir, Turkey, turhan.kahraman@yahoo.com

*This study was presented as an oral abstract at I. Adnan Menderes University International Health Sciences Congress, Aydin, Turkey, 29.06.2017-01.07.2018. 


\section{Introduction}

Balance is maintained with a variety of inputs from visual, vestibular, and somatosensory systems that are integrated into brainstem and cerebellum $(1,2)$. It is known that these parts of the central nervous system play an important role in the oculomotor and postural control $(1,2)$. High-intensity acoustic stimuli may cause a vestibular activation that causes vertigo, nystagmus and postural imbalance (2). Additionally, the vestibulocochlear nerve, brainstem, thalamus, and auditory cortex are activated while listening to music (2). Frontal cortex and limbic system which are the specific areas related to emotional behaviors are also activated with music (3-5).

Previous researchers have noted that music can improve physical function including gait and balance in several populations such as stroke, Parkinson's disease, geriatrics, and healthy people (6-10). Many studies have examined postural responses under sound stimuli to investigate their associations. In these studies, the static balance was assessed using computerized balance tools, and some studies reported no change in the static balance under the sound stimuli, whereas, some studies reported some changes $(2,11-13)$. There is no consensus on which sounds have effects on postural control (14-18). Additionally, most of the studies have examined the effects of music/sound on static balance (2, 11-13). Only one study reported that daily music listening can improve dynamic posturographic scores, which suggests that listening to music has potential to change postural stability, and can be used as a fall prevention and rehabilitation method (19). However, in that study, the dynamic posturographic measures were obtained 10 minutes, 1 week, and 1 month after music listening (19). Thus, it is still unclear how the dynamic balance is affected during listening to music.

Besides the positive effects of music, it can also have negative effects such as noise-induced hearing loss and other health effects including cardiac autonomic modulation, hypertension, and annoyance (20-25). In addition, previous studies showed that exposure to noise of high intensities may cause larger postural sway indicating the worse performance of balance $(26,27)$. On the other hand, a recent study has reported that there was a significant association of better balance with high exposure $(\geq 46.6 \mathrm{~dB})$ at $100 \mathrm{~Hz}$ compared to low exposure at $100 \mathrm{~Hz}$ in young adults (28).

Dual tasks such as walking and listening to music are considered to affect the dynamic balance necessary for functional activities by reducing the cognitive ability and fall risk can be increased $(29,30)$. Listening to music with personal listening devices such as MP3 players, smartphones, and other portal music players are very popular, especially among adolescents and young adults, while performing various activities of daily living $(29,31)$. Although there is growing research on the effects of a sound stimulus on balance control, little is available for the specific genres of music. A study revealed that listening to different genres of music did not significantly change the static balance variables in healthy people (2). However, this study compared only the effects of classical music vs. the subjects' favorite music on static balance (2). If some differences between the genres of music can be found, this genre of music can be used to make the conditions more challenging in balance and/or dual-task related rehabilitation programs. In addition, it can be advised to be more careful while listening this genre of music while performing activities of daily living. Therefore, our study aimed to investigate the effects of popular genres of music, including pop, rock, and classical, on both static and dynamic balance control, especially during common activities of daily living such as sit-tostand and walking, using both clinical and computerized balance assessment tools.

\section{Materials and Methods Participants}

Thirty-six healthy young adults aged between 18 and 25 years old participated in this crossover study. The participants were recruited from the students of School of Physical Therapy and Rehabilitation, Dokuz Eylül University, Izmir, Turkey between May 2016 and June 2016. Participants were excluded from the study if they had been diagnosed with the neurological disorder, vertigo, and hearing loss or have an orthopedic problem that could prevent the implementation of the assessments. 
The required sample size for the study was calculated using the G*Power (Version 3.1.9.2, University of Düsseldorf, Düsseldorf, Germany). Since there was no study with a similar protocol, the sample size was calculated as 34 participants to reach a medium effect size and power $=0.80$ with an alpha error probability $=0.05$.

The study was approved by the Noninvasive Research Ethics Board of Dokuz Eylül University according to the Declaration of Helsinki (Protocol No: 2677-GOA, Approval No: 2016/12-20), and all participants provided informed consent before participating in the study.

\section{Assessments}

NeuroCom ${ }^{\circledR}$ Balance Master ${ }^{\circledR}$ system (ver. 8.1; Neurocom International Inc., Oregon, USA), which is a computerized balance assessment tool, was used for the assessment of static and dynamic balance. The static balance was assessed using the modified Clinical Test Sensory Interaction on Balance (mCTSIB). The dynamic balance during the common activities of daily living was assessed using the sit-to-stand test and walk across test. Moreover, the timed up and go test (TUG) as a clinical measure was used to assess the dynamic mobility performance.

The standard protocols described in the Balance Master Operators Manual were followed in this study to perform the tests with the NeuroCom ${ }^{\circledR}$ Balance Master ${ }^{\circledR}$ system (32). All the tests were performed for three times and the computer system calculated the mean scores. During the mCTSIB, the participants were evaluated on four different conditions; (1) eyes open - firm surface, (2) eyes closed - firm surface, (3) eyes open - foam surface, and (4) eyes closed - foam surface (32). Postural sway for each condition and composite postural sway were reported. The sit-to-stand test quantifies the individual's ability to rise from a seated to standing position (32). The participants were positioned while their both legs were kept at shoulder width and feet were placed symmetrically and parallel to each other on each force plate in a sitting position on a seated surface (40.64 cm in height). Then they were asked to stand up as fast as possible without using arm support and maintain an upright posture. Weight transfer time (time required to transfer weight from the buttock to the feet), rising index (the amount of force exerted by the legs during the rising phase, expressed as a percent of body weight) and the center of gravity sway velocity in the standing position were reported. The walk across test was used to assess dynamic balance during walking (32). Step width, step length, and speed were reported.

The TUG is a simple test used to assess mobility performance and requires both static and dynamic balance (33). The participants were asked to sit on a standard chair and place his/her back against the chair and rest his/her arms chair's arms. The participants walked to a 3-meter line turned around at the line, walked back to the chair, and sat down. The test was ended when the participant's buttocks touched the seat (34). At the TUG-Cognitive test, the participants were asked to complete the test while counting backward by threes from a randomly selected number between 20 and 100 (34). At the TUG-Manual test, the participants were asked to walk while grasping a cup filled with water (34). In addition, music listening characteristics were assessed using a simple questionnaire and a $10-\mathrm{cm}$ visual analog scale.

\section{Genres of music and music tools}

"Por Una Cabeza - Carlos Gardel”, "Misery Hypnogaja, duration", and "Satellite - Lena" were used as different genres of classical, rock, and pop music, respectively. The music volume was set as 10/15 for all genres of music with an average $65 \pm 5$ decibel $(\mathrm{dB})$ measured using an Android application [Sound Meter (ver. 1.6.5a)] in each test. The same smartphone (General Mobile, Discovery) and headset (GoldMaster, HP-296) were used for listening to music in each participant.

\section{Test Procedure}

All the tests were performed in different conditions, including (1) without listening to the music, (2) listening to pop music, (3) listening to rock music, and (4) listening to classical music. The order of the tests and conditions were randomly changed for minimizing the order effect. There were six different tests with four different conditions, which simply created 24 different situations (i.e. tests). All the participant numbers were written in a Microsoft Office Excel spreadsheet before the participant recruitment. Then, for each participant number, a different testing sequence was generated using a simple randomization method generated by Microsoft 
Office Excel. The participants wore the headset during the condition without listening to music to ensure the same test conditions. All the assessments were done on the same day. Between the assessments, 1-to-5-minute intervals were given to the participants according to their perceived fatigue levels.

\section{Statistical analysis}

Normal distribution was checked with the Shapiro-Wilk test, and the $Q-Q$ plot and histogram graphics were also investigated. Descriptive statistics were used to describe the characteristics of the participants. Mean and standard deviations (SD) were reported for continuous variables, and number and percent were reported for categorical variables. The comparison of the different conditions was conducted with the repeated measures analysis of variance (ANOVA). Partial eta squared values were interpreted as small $=0.01$, medium=0.06, and large $=0.16$. Level of significance was set at $p<0.05$. All data were analyzed using IBM SPSS Statistics for Windows (Version 22.0. Armonk, NY: IBM Corp.).

\section{Results}

In total, 36 participants (18 female and 18 male) were included in the study. The mean age was $23.0(\mathrm{SD}=1.0)$ years. The mean height, weight, and body mass index were $1.70(\mathrm{SD}=0.09) \mathrm{m}$, $66.08(\mathrm{SD}=11.63) \mathrm{kg}$, and $22.64(\mathrm{SD}=3.03)$ $\mathrm{kg} / \mathrm{m}^{2}$, respectively (Table 1 ).

The participants reported that they were listening to music with a mean of 2.8 hours per day. The participants reported that they were listening to music during walking (61.1\%), travelling (66.7\%), lying down (50.0\%), and studying (50.0\%). Most of the participants (83.3\%) were listening to music with an earphone.

Table 1. Demographic characteristics of the participants

\begin{tabular}{lcc}
\hline Variables & Mean & $\begin{array}{c}\text { Standard } \\
\text { Deviation }\end{array}$ \\
\hline Age (years) & 23.0 & 1.0 \\
\hline Gender* & & \\
\hline \multicolumn{1}{c}{ Female } & 18 & 50 \\
$\quad$ Male & 18 & 50 \\
\hline Height $(\mathrm{m})$ & 1.70 & 0.09 \\
\hline Weight $(\mathrm{kg})$ & 66.08 & 11.63 \\
\hline Body mass & 22.64 & 3.03 \\
\hline index $\left(\mathrm{kg} / \mathrm{m}^{2}\right)$ &
\end{tabular}

*Presented as number and percent.
The participants reported that they liked classical, rock, and pop music with a mean 7.13 $\mathrm{cm}, 6.82 \mathrm{~cm}$, and $7.60 \mathrm{~cm}$ on a $10-\mathrm{cm}$ visual analog scale, respectively. On the other hand, the participants reported that they were listening to classical music (38.9\%), listening to rock music (61.1\%), and listening to pop music (55.6\%). The participants reported that they were familiar with the songs used in this study with $50 \%$ of classical, $36.1 \%$ of rock, and $72.2 \%$ of pop music.

No statistically significant differences were found in the static and dynamic postural control variables $(p>0.05)$. Partial eta squared values indicated that the effect sizes were small. Table 2 presents the detailed results of the comparisons.

\section{Discussion}

This study aimed to investigate not only balance performance while listening to music but also the influence of different genres of music on balance performance. The findings of this study have revealed that different genres of music including classical, rock, and pop did not have a notable influence on the static and dynamic balance in adults.

We chose to investigate the effects of classical, rock, and pop music due to their popularities. Although the participants reported that they enjoyed all genres of music used in our study, the frequency of classical music listening was relatively low compared to rock and pop. In addition, they were familiar with the songs used in this study with $50 \%$ of classical, $36.1 \%$ of rock, and $72.2 \%$ of pop music. Despite the familiarity difference in the genres of music, it seems that familiarity could not have a notable effect on dualtask performance. This finding is line with the previous studies reporting a lack of sensitivity to difficulty and lack of practice effect during dual tasks (35). In addition, music listening task might not reach a significant level to affect balance control. Because while participants were listening to music during testing protocols, they were waiting for commands from the screen or researcher, and they had targeted to the motor tasks. This might mean that participants prioritized the balance control over listening to music (36). 
Some studies have reported that there is a significant increase in body sway representing decreased static balance, especially while eyes closed, while the participants are listening to highintensity tones of low frequencies $(37,38)$. On the other hand, the other studies have not found any significant differences in the static balance with and without a sound stimulation similar to our findings $(11,39)$. However, our study differs in terms of the sound stimulus used in those studies. Only Forti et al. (2) investigated the influence of different genres of music on the static balance. That study revealed that listening to different genres of music did not significantly change the static balance variables (2). Since the participants of our study and most of the other studies were generally young, having high capacity to easily compensate for balance changes, no significant change in the static balance might be observed while listening to different genres of music.

According to the existing evidence, our study presents important findings. To the best of our knowledge, this was the first study, examining the influence of music on dynamic balance especially during the common activities of daily living assessed by a computerized tool. Hyong (29) found that dynamic balance was decreased in a dual-task which was performing a clinical

Table 2. Static and dynamic postural control while listening to different genres of music and the condition without music

\begin{tabular}{|c|c|c|c|c|c|c|c|c|}
\hline Variables & $\begin{array}{l}\text { Without } \\
\text { Music }\end{array}$ & $\begin{array}{l}\text { Classical } \\
\text { Music }\end{array}$ & $\begin{array}{l}\text { Rock } \\
\text { Music }\end{array}$ & $\begin{array}{l}\text { Pop } \\
\text { Music }\end{array}$ & $\mathbf{F}$ & $p^{*}$ & $\begin{array}{l}\text { Partial } \\
\text { Eta } \\
\text { Squared }\end{array}$ & $\begin{array}{l}\text { Observed } \\
\text { Power** }\end{array}$ \\
\hline \multicolumn{9}{|l|}{$\begin{array}{l}\text { Modified clinical test } \\
\text { sensory interaction on } \\
\text { balance }\end{array}$} \\
\hline $\begin{array}{l}\text { Eyes open on a firm } \\
\text { surface }(\% / s)\end{array}$ & $\begin{array}{c}0.34 \\
(0.38)\end{array}$ & $\begin{array}{c}0.31 \\
(0.09)\end{array}$ & $\begin{array}{c}0.29 \\
(0.09)\end{array}$ & $\begin{array}{c}0.35 \\
(0.32)\end{array}$ & 0.484 & 0.591 & 0.014 & 0.121 \\
\hline $\begin{array}{l}\text { Eyes closed on a firm } \\
\text { surface }(\% / s)\end{array}$ & $\begin{array}{c}0.32 \\
(0.10)\end{array}$ & $\begin{array}{c}0.31 \\
(0.10)\end{array}$ & $\begin{array}{c}0.29 \\
(0.08)\end{array}$ & $\begin{array}{c}0.30 \\
(0.09)\end{array}$ & 0.856 & 0.449 & 0.024 & 0.211 \\
\hline $\begin{array}{l}\text { Eyes open on a foam } \\
\text { surface }(\%)\end{array}$ & $\begin{array}{c}0.39 \\
(0.12)\end{array}$ & $\begin{array}{c}0.41 \\
(0.16)\end{array}$ & $\begin{array}{c}0.39 \\
(0.11)\end{array}$ & $\begin{array}{c}0.39 \\
(0.09)\end{array}$ & 0.380 & 0.715 & 0.011 & 0.113 \\
\hline $\begin{array}{l}\text { Eyes closed on a foam } \\
\text { surface }(\% / s)\end{array}$ & $\begin{array}{c}0.49 \\
(0.16)\end{array}$ & $\begin{array}{c}0.51 \\
(0.17)\end{array}$ & $\begin{array}{c}0.49 \\
(0.14)\end{array}$ & $\begin{array}{c}0.46 \\
(0.12)\end{array}$ & 1.349 & 0.266 & 0.037 & 0.304 \\
\hline Composite sway & $\begin{array}{c}0.40 \\
(0.15)\end{array}$ & $\begin{array}{c}0.40 \\
(0.11)\end{array}$ & $\begin{array}{c}0.38 \\
(0.08)\end{array}$ & $\begin{array}{c}0.39 \\
(0.11)\end{array}$ & 0.439 & 0.629 & 0.012 & 0.116 \\
\hline \multicolumn{9}{|l|}{ Sit-to-stand test } \\
\hline Weight transfer (s) & $\begin{array}{c}0.66 \\
(0.32)\end{array}$ & $\begin{array}{l}0.70 \\
(0.45)\end{array}$ & $\begin{array}{c}0.64 \\
(0.26)\end{array}$ & $\begin{array}{c}0.66 \\
(0.33)\end{array}$ & 0.389 & 0.679 & 0.011 & 0.110 \\
\hline Rising index (\%) & $\begin{array}{l}21.58 \\
(6.45)\end{array}$ & $\begin{array}{c}21.19 \\
(21.31)\end{array}$ & $\begin{array}{l}21.31 \\
(5.85)\end{array}$ & $\begin{array}{l}22.14 \\
(6.96)\end{array}$ & 0.841 & 0.475 & 0.023 & 0.210 \\
\hline $\begin{array}{l}\text { Centre of gravity sway } \\
\text { velocity }(\% / \mathrm{s})\end{array}$ & $\begin{array}{l}2.60 \\
(1.09) \\
\end{array}$ & $\begin{array}{c}2.45 \\
(0.95) \\
\end{array}$ & $\begin{array}{c}2.55 \\
(0.88) \\
\end{array}$ & $\begin{array}{c}2.61 \\
(0.99) \\
\end{array}$ & 0.591 & 0.609 & 0.017 & 0.164 \\
\hline \multicolumn{9}{|l|}{ Walk across test } \\
\hline Step width (cm) & $\begin{array}{l}15.80 \\
(3.41)\end{array}$ & $\begin{array}{l}15.50 \\
(3.26)\end{array}$ & $\begin{array}{l}14.95 \\
(3.49)\end{array}$ & $\begin{array}{l}15.05 \\
(3.14)\end{array}$ & 1.280 & 0.285 & 0.035 & 0.323 \\
\hline Step length (cm) & $\begin{array}{c}68.16 \\
(13.91)\end{array}$ & $\begin{array}{c}67.02 \\
(11.07)\end{array}$ & $\begin{array}{l}68.18 \\
(15.84)\end{array}$ & $\begin{array}{c}64.89 \\
(11.66)\end{array}$ & 0.730 & 0.503 & 0.020 & 0.179 \\
\hline Walk speed (cm/s) & $\begin{array}{c}85.16 \\
(13.26) \\
\end{array}$ & $\begin{array}{c}85.92 \\
(13.30) \\
\end{array}$ & $\begin{array}{c}84.45 \\
(12.68) \\
\end{array}$ & $\begin{array}{c}87.54 \\
(14.24) \\
\end{array}$ & 0.668 & 0.574 & 0.019 & 0.178 \\
\hline \multicolumn{9}{|l|}{ Timed up and go test } \\
\hline Normal (s) & $\begin{array}{l}5.20 \\
(0.60)\end{array}$ & $\begin{array}{c}5.20 \\
(0.78)\end{array}$ & $\begin{array}{l}5.23 \\
(0.73)\end{array}$ & $\begin{array}{c}5.09 \\
(0.73)\end{array}$ & 1.258 & 0.293 & 0.035 & 0.298 \\
\hline Cognitive task (s) & $\begin{array}{l}5.30 \\
(0.70)\end{array}$ & $\begin{array}{c}5.41 \\
(0.78)\end{array}$ & $\begin{array}{l}5.29 \\
(0.71)\end{array}$ & $\begin{array}{c}5.33 \\
(0.82)\end{array}$ & 0.692 & 0.536 & 0.019 & 0.179 \\
\hline Manual task (s) & $\begin{array}{c}5.59 \\
(0.66)\end{array}$ & $\begin{array}{c}5.78 \\
(0.91)\end{array}$ & $\begin{array}{l}5.70 \\
(0.72)\end{array}$ & $\begin{array}{c}5.69 \\
(0.74)\end{array}$ & 1.592 & 0.206 & 0.044 & 0.354 \\
\hline
\end{tabular}

Values are presented as mean (standard deviation).

*Repeated measures analysis of variance (ANOVA).

**Computed using alpha $=0.05$ 
dynamic balance test while listening to music. However, the balance assessment method used in that study is different from the present study and genre of music they used was not specified (29). Carrick et al. (19) investigated the effects of listening to daily certain types of music on the dynamic balance control in adults. In that study, the dynamic posturographic measures were obtained 10 minutes, 1 week, and 1 month after listening to music (19). Findings of that study suggest that daily certain types of music can improve dynamic posturographic scores demonstrating music has the potential to change postural stability and can be used as a fall prevention and rehabilitation method (19). However, our study has not revealed such a relation. Therefore, future studies should investigate the chronic effects of different genres of music on balance control.

The main strength of our study is being the first study, to the best of our knowledge, investigating the effects of popular genres of music, including pop, rock, and classical, on both static and dynamic balance control, especially during common activities of daily living such as sit-to-stand and walking, using both clinical and computerized balance assessment tools. In addition, we have reached the calculated sample size and the effect size values have indicated that the non-significant findings could not be due to inadequate sample size.

There are several potential limitations of current study. First, since our study consisted solely of young and healthy participants, generalization of the findings is difficult for other people such as older adults and people with a specific disease. Future studies conducted on those populations, especially patients with a balance disorder, are highly required. Second, we randomly selected the genres of music. However, it is known that the musical groove can influence the neural mechanisms associated with balance control (40). Future studies are warranted to investigate the effects of different musical grooves on balance control.

\section{Conclusion}

This study showed that different genres of music including classical, rock, and pop did not influence the static and dynamic balance control in young adults. The influence of different genres of music with different frequency or groove properties on balance control and chronic effects of these music genres should be investigated in future studies.

\section{Acknowledgements}

We would like to thank the physiotherapists; Duygu Çift, Berat Tatlıdil, Ensar Şimşek, İskender Emre Aydoğan, and Enes Aldemir for the assistance during the acquisition of subjects.

\section{References}

1. Baloh RW, Honrubia V, Kerber KA. Overview of Vestibular Anatomy and Physiology. In: Baloh RW, Honrubia V, Kerber KA, eds. Baloh and Honrubia's Clinical Neurophysiology of the Vestibular System. 4th ed. Oxford: Oxford University Press; 2011.

2. Forti S, Filipponi E, Di Berardino F, Barozzi $\mathrm{S}$, Cesarani A. The influence of music on static posturography. J Vestib Res. 2010;20(5):351-356.

3. Peretz I, Zatorre RJ. Brain organization for music processing. Annu Rev Psychol. 2005;56:89-114.

4. Menon V, Levitin DJ. The rewards of music listening: response and physiological connectivity of the mesolimbic system. Neuroimage. 2005;28(1):175-184.

5. Koelsch S, Siebel WA. Towards a neural basis of music perception. Trends Cogn Sci. 2005;9(12):578-584.

6. Nombela C, Hughes LE, Owen AM, Grahn JA. Into the groove: can rhythm influence Parkinson's disease? Neurosci Biobehav Rev. 2013;37(10 Pt 2):2564-2570.

7. Hamburg J, Clair AA. The effects of a movement with music program on measures of balance and gait speed in healthy older adults. J Music Ther. 2003;40(3):212-226.

8. Zhang Y, Cai J, Zhang Y, Ren T, Zhao M, Zhao Q. Improvement in Stroke-induced Motor Dysfunction by Music-supported Therapy: A Systematic Review and Metaanalysis. Sci Rep. 2016;6:38521.

9. Zhang S, Liu D, Ye D, Li H, Chen F. Can music-based movement therapy improve motor dysfunction in patients with Parkinson's disease? Systematic review and meta-analysis. Neurol Sci. 2017;38(9):1629-1636. 
10. Booth V, Hood V, Kearney F. Interventions incorporating physical and cognitive elements to reduce falls risk in cognitively impaired older adults: a systematic review. JBI Database System Rev Implement Rep. 2016;14(5):110-135.

11. Palm HG, Strobel J, Achatz G, von Luebken $\mathrm{F}$, Friemert B. The role and interaction of visual and auditory afferents in postural stability. Gait Posture. 2009;30(3):328-333.

12. Tanaka $\mathrm{T}$, Kojima $\mathrm{S}$, Takeda $\mathrm{H}$, Ino $\mathrm{S}$, Ifukube $\mathrm{T}$. The influence of moving auditory stimuli on standing balance in healthy young adults and the elderly. Ergonomics. 2001;44(15):1403-1412.

13. Nazareth I, Landau S, Yardley L, Luxon L. Patterns of presentations of dizziness in primary care--a cross-sectional cluster analysis study. J Psychosom Res. 2006;60(4):395-401.

14. Soames RW, Raper SA. The influence of moving auditory fields on postural sway behaviour in man. Eur J Appl Physiol Occup Physiol. 1992;65(3):241-245.

15. Agaeva MY, Al'tman YA, Kirillova IY. Effects of a sound source moving in a vertical plane on postural responses in humans. Neurosci Behav Physiol. 2006;36(7):773-780.

16. Hegeman J, Honegger F, Kupper M, Allum $\mathrm{JH}$. The balance control of bilateral peripheral vestibular loss subjects and its improvement with auditory prosthetic feedback. J Vestib Res. 2005;15(2):109-117.

17. Dozza M, Horak FB, Chiari L. Auditory biofeedback substitutes for loss of sensory information in maintaining stance. Exp Brain Res. 2007;178(1):37-48.

18. Ross JM, Balasubramaniam R. Auditory white noise reduces postural fluctuations even in the absence of vision. Exp Brain Res. 2015;233(8):2357-63.

19. Carrick FR, Oggero E, Pagnacco G. Posturographic changes associated with music listening. J Altern Complement Med. 2007;13(5):519-526.

20. Jiang W, Zhao F, Guderley N, Manchaiah V. Daily music exposure dose and hearing problems using personal listening devices in adolescents and young adults: A systematic review. Int J Audiol. 2016;55(4):197-205.
21. Serra MR, Biassoni EC, Hinalaf M, Abraham M, Pavlik M, Villalobo JP, et al. Hearing and loud music exposure in 14-15 years old adolescents. Noise Health. 2014;16(72):320330.

22. do Amaral JA, Guida HL, Vanderlei FM, Garner DM, de Abreu LC, Valenti VE. The Effects of Musical Auditory Stimulation of Different Intensities on Geometric Indices of Heart Rate Variability. Altern Ther Health Med. 2015;21(5):16-23.

23. Chang TY, Liu CS, Young LH, Wang VS, Jian SE, Bao BY. Noise frequency components and the prevalence of hypertension in workers. Sci Total Environ. 2012;416:89-96.

24. Chang TY, Liu CS, Huang KH, Chen RY, Lai JS, Bao BY. High-frequency hearing loss, occupational noise exposure and hypertension: a cross-sectional study in male workers. Environ Health. 2011;10:35.

25. Pawlaczyk-Luszczynska M, Dudarewicz A, Waszkowska M, Sliwinska-Kowalska M. Assessment of annoyance from low frequency and broadband noises. Int J Occup Med Environ Health. 2003;16(4):337-343.

26. Golz A, Westerman ST, Westerman LM, Goldenberg D, Netzer A, Wiedmyer T, et al. The effects of noise on the vestibular system. Am J Otolaryngol. 2001;22(3):190-196.

27. Juntunen J, Matikainen E, Ylikoski J, Ylikoski M, Ojala M, Vaheri E. Postural body sway and exposure to high-energy impulse noise. Lancet. 1987;2(8553):261-264.

28. Xu H, Ohgami N, He T, Hashimoto K, Tazaki A, Ohgami K, et al. Improvement of balance in young adults by a sound component at $100 \mathrm{~Hz}$ in music. Sci Rep. 2018;8(1):16894.

29. Hyong IH. The effects on dynamic balance of dual-tasking using smartphone functions. J Phys Ther Sci. 2015;27(2):527-529.

30. Serrador JM, Lipsitz LA, Gopalakrishnan GS, Black FO, Wood SJ. Loss of otolith function with age is associated with increased postural sway measures. Neurosci Lett. 2009;465(1):10-15.

31. Ansari H, Mohammadpoorasl A. Using earphone and its complications: an increasing pattern in adolescents and young adults. health scope. 2016;5(1):e32130. 
32. NeuroCom International, Inc. Instructions for use: Balance Master System operator's manual. Version 8.1. Clackamas: NeuroCom International, Inc.; 2003.

33. Hafsteinsdottir TB, Rensink M, Schuurmans M. Clinimetric properties of the Timed Up and Go Test for patients with stroke: a systematic review. Top Stroke Rehabil. 2014;21(3):197-210.

34. Shumway-Cook A, Brauer S, Woollacott M. Predicting the probability for falls in community-dwelling older adults using the Timed Up \& Go Test. Phys Ther. 2000;80(9):896-903.

35. Cocchini G, Filardi MS, Crhonkova M, Halpern AR. Musical expertise has minimal impact on dual task performance. Memory. 2017;25(5):677-685.

36. McNevin NH, Wulf G. Attentional focus on supra-postural tasks affects postural control. Hum Mov Sci. 2002;21(2):187-202.

37. Russolo M. Sound-evoked postural responses in normal subjects. Acta Otolaryngol. 2002;122(1):21-27.

38. Alessandrini M, Lanciani R, Bruno E, Napolitano B, Di Girolamo S. Posturography frequency analysis of sound-evoked body sway in normal subjects. Eur Arch Otorhinolaryngol. 2006;263(3):248-252.

39. Mainenti MRM, De Oliveira LF, De Melo Tavares De Lima MA, Nadal J. Stabilometric signal analysis in tests with sound stimuli. Exp Brain Res. 2007;181(2):229-36.

40. Ross JM, Warlaumont AS, Abney DH, Rigoli $\mathrm{LM}$, Balasubramaniam R. Influence of musical groove on postural sway. J Exp Psychol Hum Percept Perform. 2016;42(3):308-319. 